\title{
Artificial rearing of pigs
}

\section{6*. The effect of different levels of fat, protein and methionine in a milk-substitute diet containing skim milk and soya-bean oil}

\author{
BY R. BRAUDE, H. D. KEAL AND M. J. NEWPORT \\ National Institute for Research in Dairying, Shinfield, Reading $R G_{2}{ }_{9} A T$
}

$$
\text { (Received } 23 \text { February } 1976 \text { - Accepted } 30 \text { fuly 1976) }
$$

\footnotetext{
I. Protein and energy requirements of pigs weaned at $2 \mathrm{~d}$ of age were studied. In Expt $\mathrm{I}$, three diets with crude protein (CP; nitrogen $\times 6.38$ ) and fat contents ( $\mathrm{g} / \mathrm{kg}$ dry matter (DM)) of 268,260 (diet A); 216,415 (diet B) and 264,405 (diet C) were compared, with and without a supplement of $\mathbf{2} \mathbf{g}$ DL-methionine/kg. Diets $A$ and $B$ contained skim milk and soya-bean oil only, in different proportions. Casein was added to diet $C$ to equalize the $C P$ content to that of diet A. In Expt 2, diets containing 290 or $315 \mathrm{~g} \mathrm{CP} / \mathrm{kg} \mathrm{DM}$ were used with either 310 or $405 \mathrm{~g}$ fat $/ \mathrm{kg}$. The diets contained different proportions of skim milk, soya-bean oil and casein. The same diets as used in Expt 2 were used in Expt 3 but fed to a scale based on live weight which was $25 \%$ less than that used in Expts $I$ and 2.

2. Methionine supplementation had no significant effect $(P>0.05)$ on the growth rate or feed : gain ratio of pigs from 2 to $28 \mathrm{~d}$ of age. The growth rate of the pigs from 2 to $28 \mathrm{~d}$ of age was significantly $(P<0.05)$ reduced when they were given the higher level of either $\mathrm{CP}$ or fat, with the exception that the effect of level of fat was not significant $(P>0.05)$ in Expt 3 . The reduction in growth rate was associated with a decrease in feed intake. Feed: gain ratios were unaffected $(P>0.05)$ by the level of either $C P$ or fat in the diet.

3. The higher protein level did increase the proportion of CP in the carcass DM (Expt 2 $P<0.01$, Expt $3 P>0.05)$ and gave an indication, which was not significant $(P>0.05)$, of improved $\mathrm{N}$ retention ( $\mathrm{g} / \mathrm{d}$ per $\mathrm{kg}$ live weight). The higher dietary fat level increased the proportion of lipid in the carcass DM, and this effect was significant $(P<0.05)$ in both Expts 2 and 3.

4. Diets containing additional casein were not fully consumed at the level of feeding used in Expt 2. This effect may be associated with the larger amounts of digesta in the stomachs of these pigs. Some differences in the composition of the digesta in the stomach were observed, but these did not affect the performance of the pigs.

5. It seems unlikely that either growth rate or feed:gain ratio (g DM consumed/g liveweight gain) can be improved by protein or energy levels exceeding those in a diet containing (g/kg DM) 730 skim milk $(265-290 \mathrm{CP})$ and 3 I 0 fat. In this diet, containing (g/kg DM) 6.4 methionine and 3.5 cystine, sulphur amino acid requirements were satisfied.
}

In a previous experiment (Braude, Keal \& Newport, 1976) the live-weight gain and feed: gain ratio of baby pigs given milk-substitute diets did not respond to an increase in the energy content of the diet. However, as these diets were formulated by the direct replacement of skim milk by fat, in the form of soya-bean oil, the absence of a response to the increased energy content may well have been due to the decreased protein content. This possibility has now been studied in a factorial experiment in which two levels of protein and fat were fed.

The sulphur-containing amino acid requirements of young pigs have been calculated to be $13 \mathrm{~g} / \mathrm{kg}$ dry matter (DM) for pigs of $1.4-4.5 \mathrm{~kg}$ live weight receiving a diet containing $320 \mathrm{~g}$ protein $/ \mathrm{kg}$, and $9 \mathrm{~g}$ S-containing amino acids $/ \mathrm{kg}$ DM for pigs of $4.5^{-}$

* Paper no. $5:$ Br. F. Nutr. (1976) 35, 253. 
Table I. Composition of the experimental diets fed to baby pigs

(a) Expt I

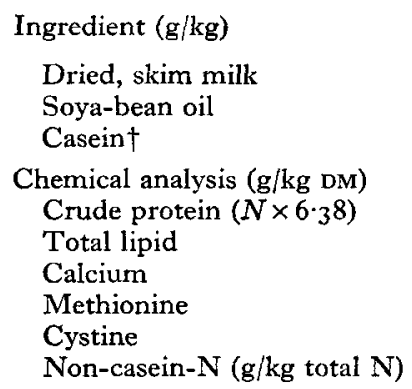
Dried, skim milk
Soya-bean oil
Casein $\dagger$

Ingredient $(\mathrm{g} / \mathrm{kg})$

Chemical analysis (g/kg DM)

Crude protein

Total lipid

Calcium

Non-casein-N (g/kg total $N$ ) (b) Expts 2 and 3

\begin{tabular}{ccr}
\multicolumn{3}{c}{ Diet* } \\
$\overbrace{730}$ & 600 & C \\
270 & 400 & 530 \\
- & - & 400 \\
& & 70 \\
268.0 & 216.0 & 264.0 \\
260.0 & 415.0 & 405.0 \\
10.6 & 8.6 & 8.4 \\
6.4 & 5.9 & 6.8 \\
3.5 & 3.1 & 2.9 \\
190 & 192 & 147
\end{tabular}

DM, dry matter.

* Each diet was fed with or without $2 \mathrm{~g}$ DL-methionine $/ \mathrm{kg}$.

$\dagger$ Calcium caseinate, 'Casilan'; Glaxo Ltd, Greenford, Middlesex.

Diet

\begin{tabular}{cccc}
\hline A & D & E & F \\
730 & 670 & 524 & 464 \\
270 & 270 & 400 & 400 \\
- & 60 & 76 & 136 \\
& & & \\
291.0 & 318.0 & 287.0 & 315.0 \\
305.0 & 315.0 & 397.0 & 415.0 \\
10.8 & 10.1 & 9.0 & $8 \cdot 5$ \\
189 & 162 & 134 & 120
\end{tabular}

$9.0 \mathrm{~kg}$ live weight when given a diet containing $260 \mathrm{~g}$ protein $/ \mathrm{kg}$ (Agricultural Research Council, I967). These values indicate that a milk-protein diet containing $260 \mathrm{~g}$ protein $/ \mathrm{kg}$ will be deficient in S-containing amino acids for pigs up to $4.5 \mathrm{~kg}$ live weight, and for pigs of $4^{\cdot} 5^{-} 9^{\circ} \circ \mathrm{kg}$ live weight the requirement will only just be satisfied if the diet contains only $220 \mathrm{~g}$ protein $/ \mathrm{kg}$. Therefore, the effect of methionine supplementation was studied in one experiment.

\section{EXPERIMENTAL}

\section{Diets}

Either three (Expt I) or four diets (Expts 2 and 3 ) were prepared from mixtures of soya-bean oil and skim milk and were subsequently spray-dried by a mild-heat process to prevent denaturation of the whey proteins. Preparation of liquid diets containing $200 \mathrm{~g}$ total solids/ 1 from these powders and supplementation with retinol cholecalciferol, $\alpha$-tocopherol and phylloquinone was carried out as previously described (Braude \& Newport, I 973). The addition of casein to some of the diets was made after spray-drying. The composition of these diets is shown in Table I. 


\section{Scale of feeding}

In Expts $I$ and 2, the pigs were fed at hourly intervals on the scale described by Braude \& Newport (1973). As there was some refusal of feed when pigs were given the diets containing additional casein, the scale of feeding was reduced by $25 \%$ in Expt 3 so that feed intake would be equal for all diets.

\section{Experimental design and statistical analysis}

Litter-mate, 2-d-old pigs were allocated to treatments (diets) on the basis of live weight and sex. The pigs on each of the treatments were kept in separate rooms. There were usually four 'litter-mate' blocks in each replicate of an experiment. The treatment for pigs in each room was varied between replicates. Some 'litter-mate' blocks were excluded from the analysis after half or more of the pigs in a block died following a period of scouring. The results were analysed by an analysis of variance and missing values calculated by an iterative procedure. The design and analysis of each experiment was as follows:

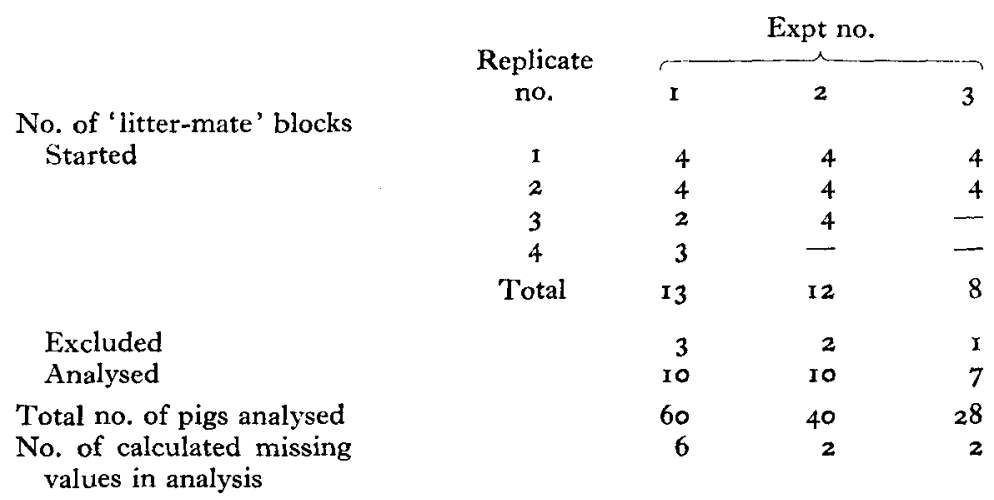

\section{Nitrogen retention and procedure at slaughter}

$\mathrm{N}$ retention was estimated from collection periods, each of $4 \mathrm{~d}$ duration, as previously described (Braude et al. 1976).

At $28 \mathrm{~d}$ of age the pigs, which were consuming all of their diet immediately after it was given and were not scouring, were killed $\mathrm{I} h$ after a feed by an intracardiac injection of sodium pentobarbitone. The stomach was removed, and the digesta emptied and stored at $-20^{\circ}$. The remainder of the alimentary tract was removed and discarded, and the carcass stored at $-20^{\circ}$. Samples of the carcass were prepared for chemical analysis as described by Florence \& Mitchell (1972).

\section{Analytical methods}

The determinations of $\mathrm{DM}$, ash, total and non-casein- $\mathrm{N}$, and total lipid have been described by Braude, Mitchell, Newport \& Porter (1970) and Braude \& Newport (1973). Calcium was determined by atomic absorption spectroscopy of ashed samples. Stomach digesta were analysed for sugars by high-pressure, anion-exchange chromatography of their borate complexes (Smith \& McAllan, r 969 ), and for total reducing 
Table 2. Expt I. Performance of baby pigs between 2 and $28 d$ of age when given diets containing different levels ( $\mathrm{g} / \mathrm{kg}$ dry matter (DM)) of crude protein $\left(C P ; N \times 6 \cdot 3^{8}\right)$ or fat, with or without methionine $(M)$ supplementation $(2 \mathrm{~g} / \mathrm{kg} \mathrm{DM})$

(Mean values for ten pigs/treatment)

\begin{tabular}{|c|c|c|c|c|c|c|c|c|}
\hline & & & & Diet cc & osition & & & \\
\hline Diet & $\ldots$ & A & AM & $\mathrm{B}$ & $\mathrm{BM}$ & $\mathrm{C}$ & CM & Standard \\
\hline & $\ldots$ & & & & & & & mean \\
\hline Fat & $\ldots$ & & & & & & & $(4 \mathrm{I} d f)$ \\
\hline $\begin{array}{l}\text { Live-wt gain (g/c } \\
\text { Feed:gain ratio } \\
\text { consumed/g liv } \\
\text { gain) }\end{array}$ & & $\begin{array}{l}344 \\
0.81\end{array}$ & $\begin{array}{r}322 \\
0.83\end{array}$ & $\begin{array}{l}315 \\
0.81\end{array}$ & $\begin{array}{l}306 \\
0.82\end{array}$ & $\begin{array}{l}323 \\
0.79\end{array}$ & $\begin{array}{r}322 \\
0.79\end{array}$ & $\begin{array}{l}10.4 \\
0.018\end{array}$ \\
\hline No. of deaths* & & I & I & I & $\circ$ & 2 & I & - \\
\hline
\end{tabular}

The only significant difference $(P<0.05)$ was in the live-weight gain of pigs given diets $\mathrm{A}$ and $\mathrm{BM}$. Mean initial live wt of pigs was $1.53 \mathrm{~kg}$ for each treatment.

* Three blocks of litter-mates are also excluded, after three or more pigs in each block died after scouring.

sugars by the method of Somogyi (1945). The methionine and cystine contents of the diets were estimated using an automatic amino acid analyser (Model $5 \mathrm{AH}$; Japan Electron Optics Laboratory Co. Ltd, Tokyo, Japan) using the method described by Moore, Spackman \& Stein (I955) and Spackman, Stein \& Moore (r958) after performic acid oxidation (Moore, 1963) of samples.

\section{RESULTS}

\section{Performance and $N$ retention}

In Expt I (Table 2), increasing the level of fat in the diet from 260 to $410 \mathrm{~g} / \mathrm{kg} \mathrm{DM}$ did not alter performance between 2 and $28 \mathrm{~d}$ of age except for a marginally lower weight gain when the crude protein ( $\mathrm{CP} ; \mathrm{N} \times 6.38$ ) content of the diet was simultaneously reduced from 268 to $216 \mathrm{~g} / \mathrm{kg}$ DM. Methionine supplementation had no effect on performance.

In Expt 2, live-weight gain was reduced when either the fat or CP levels (g/ $/ \mathrm{kg} \mathrm{DM}$ ) in the diet were increased from 310 to 405 and 290 to 315 respectively (Table 3 ), but this was confounded with large differences in feed intake. Increasing amounts of refusals occurred as the amount of casein was increased, although all four diets were offered in the same amounts $/ \mathrm{kg}$ live weight. The scale of feeding was reduced by $25 \%$ in Expt 3, and differences in feed consumption between diets were considerably reduced. The level of fat in the diet did not significantly $(P>0.05)$ affect live-weight gain and feed:gain ratio, although there was a significant $(P<0.05)$ reduction in weight gain at the higher protein level. The few measurements of $\mathrm{N}$ retention, determined between 4 and $8 \mathrm{~d}$ of age, indicated little effect of either dietary protein or fat level, although the highest mean value was found on the diet with the higher protein and fat level. 
Table 3. Expts 2 and 3. Performance and nitrogen retention of baby pigs between 2 and $28 d$ of age given diets containing different levels ( $\mathrm{g} / \mathrm{kg}$ dry matter (DM)) of crude protein $\left(C P ; N \times 6 \cdot 3^{8}\right)$ or fat

('There were ten pigs/treatment, of mean initial live wt $1.57 \mathrm{~kg}$ in Expt 2 and seven pigs/treatment of mean initial live wt $x \cdot 63 \mathrm{~kg}$ in Expt 3 . Two blocks of litter-mates were excluded from the values from Expt 2, as two or three pigs in the block died after scouring. In Expt 3, one block was excluded due to exceptionally poor performance of the pigs. In addition, missing values were calculated for one pig each on diets D and F (Expt 2), and A and E (Expt 3))

\begin{tabular}{|c|c|c|c|c|c|c|c|c|c|}
\hline \multirow{2}{*}{\multicolumn{2}{|c|}{$\begin{array}{ll} & \\
& \\
\text { Diet } & \ldots \\
\text { CP } & \ldots \\
\text { Fat } & \ldots\end{array}$}} & \multicolumn{6}{|c|}{ Diet composition } & \multicolumn{2}{|c|}{$\begin{array}{l}\text { Statistical } \\
\text { significance } \\
\text { of the } \\
\text { effect of: }\end{array}$} \\
\hline & & $\begin{array}{l}\text { Expt } \\
\text { no. }\end{array}$ & $\begin{array}{c}A \\
291 \\
305\end{array}$ & $\begin{array}{l}\mathrm{D} \\
318 \\
3 \text { I } 5\end{array}$ & $\begin{array}{c}\mathrm{E} \\
287 \\
397\end{array}$ & $\begin{array}{l}F \\
315 \\
415\end{array}$ & $\begin{array}{l}\text { Standard } \\
\text { error } \\
\text { of mean }\end{array}$ & $\begin{array}{l}\text { Protein } \\
\text { level }\end{array}$ & $\begin{array}{r}\text { Fat } \\
\text { level }\end{array}$ \\
\hline Live-wt gain (g/d) & & $\begin{array}{l}2 \\
3\end{array}$ & $\begin{array}{l}295 \\
254\end{array}$ & $\begin{array}{l}270 \\
224\end{array}$ & $\begin{array}{l}261 \\
234\end{array}$ & $\begin{array}{l}234 \\
223\end{array}$ & $\begin{aligned} 12 \cdot 3 & (26 \mathrm{df}) \\
8 \cdot 3 & (\mathrm{I} 7 \mathrm{df})\end{aligned}$ & $*$ & NS \\
\hline $\begin{array}{l}\text { Feed consumed ( } \mathrm{g} / \mathrm{kg} \\
\text { feed offered) }\end{array}$ & & $\begin{array}{l}2 \\
3\end{array}$ & $\begin{array}{l}937 \\
971\end{array}$ & $\begin{array}{l}872 \\
942\end{array}$ & $\begin{array}{l}886 \\
947\end{array}$ & $\begin{array}{l}787 \\
92 \mathrm{I}\end{array}$ & $\begin{aligned} I 1 \cdot 7 & (26 \mathrm{df}) \\
8.0 & (17 \mathrm{df})\end{aligned}$ & $* *$ & $* * *$ \\
\hline $\begin{array}{l}\text { Feed:gain ratio (g D } \\
\text { consumed/g live-w } \\
\text { gain) }\end{array}$ & & $\begin{array}{l}2 \\
3\end{array}$ & $\begin{array}{l}0.81 \\
0.75\end{array}$ & $\begin{array}{l}0.82 \\
0.80\end{array}$ & $\begin{array}{l}0.83 \\
0.74\end{array}$ & $\begin{array}{l}0.85 \\
0.77\end{array}$ & $\begin{array}{l}0.013(26 \mathrm{df}) \\
0.029(17 \mathrm{df})\end{array}$ & $\begin{array}{l}\text { NS } \\
\text { NS }\end{array}$ & $\begin{array}{l}\text { NS } \\
\text { NS }\end{array}$ \\
\hline $\begin{array}{l}N \text { retention } \dagger(g / d \text { per } \\
\quad k g \text { live } w t)\end{array}$ & & 3 & $2 \cdot 52$ & $2 \cdot 55$ & $2 \cdot 48$ & $2 \cdot 82$ & $0.115(8 \mathrm{df})$ & NS & NS \\
\hline
\end{tabular}

\section{Carcass composition}

Increasing the protein level in the diet increased the protein content and decreased the lipid content of the carcass DM. When the fat level in the diet was increased, an increase in the lipid content of the carcass DM was found and there was an indication of a decrease in the protein content (Table 4 ). The higher level of fat in the diet reduced the ash content of the carcass which may have reflected the lower Ca content of the high-fat diets (see Table $\mathrm{r}$ ).

\section{Amount and composition of digesta}

The stomachs of the pigs given the diets supplemented with casein (diets $\mathrm{D}, \mathrm{E}$ and F) contained considerably more digesta than those of pigs given diet A (Table 5). Two samples of stomach digesta were analysed for sugars and only lactose was detected. All samples were analysed for total reducing sugars and the results expressed as lactose equivalents. The only significant effect of increasing the dietary protein level on the composition of the stomach digesta was a reduction in the lactose content of the digesta. The lipid content of the digesta was increased when diets containing the higher fat levels were consumed. 
Table 4. Expts 2 and 3. Carcass weight and proportions of dry matter (DM), crude protein $\left(C P ; N \times 6 \cdot 3^{8}\right)$, total lipid and ash for 28-d-old baby pigs given diets containing different levels ( $\mathrm{g} / \mathrm{kg} \mathrm{DM})$ of $\mathrm{CP}$ or fat

(There were six pigs/treatment in Expt 2, and four pigs/treatment in Expt 3. Standard error of mean based on $14 \mathrm{df}(\operatorname{Expt} 2)$ and $10 \mathrm{df}(\operatorname{Expt} 3)$. In Expt 2, the values for diets $\mathrm{D}$ and $\mathrm{F}$ each contain one calculated missing value)

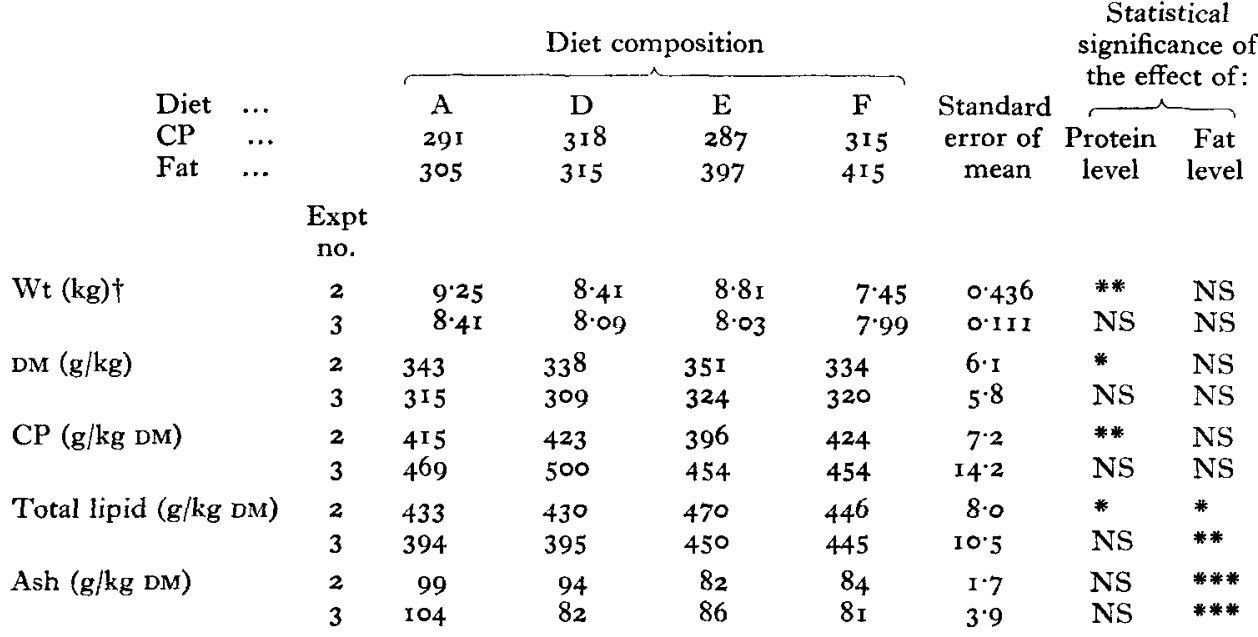

NS, not significant $(P>0.05)$.

Statistical significance of effect: $* P<0.05$, * $P<0.01, * * * P<0.001$.

$\uparrow$ Represents $89-94 \%$ live wt.

Table 5. Expt 3. The amount and composition of the stomach digesta of 28-d-old baby pigs given diets containing different levels ( $\mathrm{g} / \mathrm{kg}$ dry matter (DM)) of crude protein (CP; $N \times 6.38)$ and fat

(Mean values for four pigs/treatment. One missing value was calculated for diet $F$.)

\begin{tabular}{|c|c|c|c|c|c|c|c|}
\hline \multirow{4}{*}{$\begin{array}{l}\text { Diet } \\
\text { CP } \\
\text { Fat }\end{array}$} & \multicolumn{4}{|c|}{ Diet composition } & \multirow{4}{*}{$\begin{array}{c}\text { Standard } \\
\text { error of } \\
\text { mean } \\
(8 \mathrm{df})\end{array}$} & \multirow{2}{*}{\multicolumn{2}{|c|}{$\begin{array}{l}\text { Statistical } \\
\text { significance of } \\
\text { the effect of: }\end{array}$}} \\
\hline & A & $\mathrm{D}$ & $\mathbf{E}$ & $\mathbf{F}$ & & & \\
\hline & 291 & 318 & 287 & 315 & & Protein & Fat \\
\hline & 305 & 315 & 397 & 415 & & level & level \\
\hline $\begin{array}{l}\mathrm{DM}(\mathrm{g} / \mathrm{kg}) \\
\text { Total DM (g) }\end{array}$ & $\begin{array}{r}214 \\
8.5\end{array}$ & $\begin{array}{l}23 I \\
2 I \cdot 3\end{array}$ & $\begin{array}{l}235 \\
19 \cdot 4\end{array}$ & $\begin{array}{l}293 \\
25 \cdot 7\end{array}$ & $\begin{array}{l}39 \cdot 0 \\
6 \cdot 88\end{array}$ & $\begin{array}{l}\text { NS } \\
\text { NS }\end{array}$ & $\begin{array}{l}\text { NS } \\
\text { NS }\end{array}$ \\
\hline $\mathrm{CP}(\mathrm{g} / \mathrm{kg} \mathrm{DM})$ & 359 & 360 & 341 & 345 & $8 \cdot 2$ & NS & NS \\
\hline $\begin{array}{l}\text { Total lipid (g/kg DM) } \\
\text { Ash (g/kg DM) }\end{array}$ & $\begin{array}{r}475 \\
37\end{array}$ & $\begin{array}{r}532 \\
27\end{array}$ & $\begin{array}{r}562 \\
27\end{array}$ & $\begin{array}{r}601 \\
23\end{array}$ & $\begin{aligned} 3 I \cdot 2 \\
2 \cdot 2\end{aligned}$ & $\begin{array}{l}\text { NS } \\
\text { NS }\end{array}$ & NS \\
\hline Lactose (g/kg DM) & $\begin{array}{l}37 \\
86\end{array}$ & $\begin{array}{l}27 \\
59\end{array}$ & $\begin{array}{l}27 \\
79\end{array}$ & $\begin{array}{l}23 \\
55\end{array}$ & $8 \cdot 5$ & $*$ & NS \\
\hline Total analysed (g/kg DM) & 957 & 978 & 1009 & 1024 & & & \\
\hline
\end{tabular}

NS, not significant $(P>0.05)$.

Statistical significance of effect: $* P<0.05$. 


\section{DISCUSSION}

The performance of the pigs from 2 to $28 \mathrm{~d}$ of age was not improved by increasing either dietary CP level from 290 to $320 \mathrm{~g} / \mathrm{kg} \mathrm{DM}$, or by increasing dietary fat level from 3 IO to $400 \mathrm{~g} / \mathrm{kg}$ DM. There was an indication that daily $\mathrm{N}$ retention $(\mathrm{g} / \mathrm{kg}$ live weight) was increased when diet $\mathrm{F}$ (containing ( $/ \mathrm{kg} \mathrm{DM}) 320 \mathrm{CP}$ and 400 fat) was fed, although too few measurements were obtained to draw definite conclusions. The $\mathrm{N}$ retention measurements do, in part, agree with the information on carcass composition in that a greater content of $C P$ was found in the carcass of pigs consuming the higher-protein diets. In experiments with pigs between 14 and $42 \mathrm{~d}$ of age given diets containing milk proteins, Kirchgessner \& Kellner (1972) found greater N retention and protein content in the carcass with diets containing up to $390 \mathrm{~g} \mathrm{CP} / \mathrm{kg}$, although maximum weight gains were obtained at $260 \mathrm{~g} \mathrm{CP} / \mathrm{kg}$ diet. In a further experiment, Müller \& Kirchgessner (1974) reported that $240 \mathrm{~g} \mathrm{CP} / \mathrm{kg}$ DM gave maximum performance between 14 and $42 \mathrm{~d}$ of age, but $340 \mathrm{~g} \mathrm{CP} / \mathrm{kg}$ DM was required for maximum $\mathrm{N}$ retention.

The amount of DM in the stomach was increased by increasing either protein or fat levels in the diet. Only four measurements were made for each diet, and there was a large variation between individual pigs. The differences indicated that, in pigs on the higher protein and fat levels, the diet was retained for a longer period in the stomach. The percentage difference between the higher and lower levels of fat in the diets was greater than the corresponding difference in the lipid content of the stomach digesta, indicating that the fat was retained for a shorter time after the high-fat diets were consumed.

The addition of casein to the diets had a marked effect on feed intake in Expt 2 when the diets were fed to scale E (see Braude \& Newport, 1973), but had little effect when the level of feeding was reduced by $25 \%$ in Expt 3 . The reduced feed intakes in Expt. 2 may be associated with the larger amounts of digesta in the stomach of the pigs given casein-containing diets.

It is concluded that the performance of baby pigs between 2 and $28 \mathrm{~d}$ of age was not improved by increasing the dietary CP to a level greater than $270 \mathrm{~g} / \mathrm{kg} \mathrm{DM}$, and that the S-containing amino acid content of $9.9 \mathrm{~g} / \mathrm{kg} \mathrm{DM}$ was not limiting performance. Manners \& McCrea (1962) reported a protein requirement of $25^{\circ} \mathrm{g} / \mathrm{kg}$ diet for pigs of the same age which were given diets based on milk proteins and which contained less than $10 \mathrm{~g}$ fat $/ \mathrm{kg}$ diet. A greater requirement, $308 \mathrm{~g}$ protein $/ \mathrm{kg}$ diet, was found when the diet contained $2 \mathrm{I} \circ \mathrm{g}$ fat $/ \mathrm{kg}$ (Manners \& McCrea, I963). In our experiments, increasing the protein content of the diet to $320 \mathrm{~g} / \mathrm{kg}$, greater than the level giving maximum performance, increased the protein content of the carcass. Kirchgessner $\&$ Kellner (1972) have also reported that carcass protein content can be increased at dietary protein levels exceeding that required for maximum weight gain.

Performance was not improved by increasing the fat content of a diet based on skim milk to more than $270 \mathrm{~g}$ fat $/ \mathrm{kg} \mathrm{DM}$, although the carcass lipid content was increased. Differences in the amount and composition of the digesta in the stomach did not affect performance. 


\section{REFERENCES}

Agricultural Research Council (1967). The Nutrient Requirements of Farm Livestock No. 3, Pigs. London: Agricultural Research Council.

Braude, R., Keal, H. D. \& Newport, M. J. (r976). Br. F. Nutr. 35, 253.

Braude, R., Mitchell, K. G., Newport, M. J. \& Porter, J. W. G. (r970). Br. F. Nutr. 24, 50r.

Braude, R. \& Newport, M. J. (1973). Br. F. Nutr. 29, 447.

Florence, E. \& Mitchell, K. G. (1972). Proc. Br. Soc. Anim. Prod. 1, I01.

Kirchgessner, M. \& Kellner, B. B. (1972). Arch. Tierernähr. 22, 249.

Manners, M. J. \& McCrea, M. R. (1962). Br. F. Nutr. 16, 475.

Manners, M. J. \& McCrea, M. R. (1963). Br. F. Nutr. 17, 357.

Moore, S. J. (1963). F. biol. Chem. 238, 235.

Moore, S. J., Spackman, D. H. \& Stein, W. H. (1958). Analyt. Chem. 30, I185.

Müller, H. L. \& Kirchgessner, M. (1974). Z. Tierphysiol. Tierernähr. Futtermittelk. 33, 98.

Smith, R. H. \& McAllan, A. B. (1969). Automation in Analytical Chemistry. Technicon International Symposium, p. 207. Basingstoke, Hants: Technicon Instruments Co. Ltd.

Sornogyi, M. (1945). F. biol. Chem. 160, 6r.

Spackman, D. H., Stein, W. H. \& Moore, S. J. (1958). Analyt. Chem. 30, 1190. 